\title{
THE ORDINAL NUMBERS IN HESIOD'S MYTH OF THE RACES
}

\author{
PAULO ALEXANDRE LIMA \\ NOVA University of Lisbon \\ plima@fcsh.unl.pt
}

\begin{abstract}
To understand the meaning and function of the ordinal numbers in the myth of the races it is essential to have a full grasp of how the myth is composed and its structure is supposed to be perceived by a listener or reader. There is a general silence among Hesiod scholars about the meaning and function of the ordinal numbers in the myth. A tacit agreement may be inferred from such a silence: the ordinal numbers are implicitly taken to merely express the chronological order of the races. In this article, I examine each and every one of the ordinal numbers that appear in Hesiod's myth. I demonstrate that the ordinal numbers preserve their hierarchical dimension even in the cases in which this appears to be less convincing.
\end{abstract}

Keywords: Hesiod, myth of the races, ordinal numbers.

I

To understand the meaning and function of the ordinal numbers in the myth of the five races it is essential to have a full grasp of the way in which Hesiod's myth is composed and how its structure is supposed to be perceived by a listener or reader. In this article, I intend to develop a thorough and nuanced interpretation of the meaning and function of the ordinal numbers in the Hesiodic myth of the races. The main thesis of the article is that the ordinal numbers occurring in the myth bear both a chronological and an overall hierarchical sense.

G. W. Most $(1998,109)$ claims that Hesiod's myth does not have just one organizing principle. He argues against the view that the only organizing principle of the myth is the ordinal numbers. My position differs from his for two reasons. First, Most does not think that the ordinal numbers occurring in the Hesiodic myth are hierarchical. Secondly, the perspective that will be developed in this 
article is one according to which the ordinal numbers are just one of several organizing principles in Hesiod's myth. Nevertheless, the richness of the way in which the myth is composed and communicated cannot be completely and adequately grasped unless due attention is given to the role the ordinal numbers play (insofar as they have both a chronological and a hierarchical sense) in the structuring of the myth of the races as a whole. ${ }^{1}$

Throughout the article a lot will be said about the relative value of the races. I will favour the view that the whole Hesiodic account of the races and their succession reflects a general progressive degeneration. The article's main thesis will be backed up by this view as one of its main points of support. Since the idea of a general progressive degeneration of the races still remains the most widely accepted view, I will try to be very brief on this question and will (for the most part) rely on the work done by previous scholars. ${ }^{2} \mathrm{~A}$ few more controversial points will nevertheless be the subject of a more detailed discussion. If, on the one hand, from the point of view of the demonstration of the article's thesis, the description of each race confirms the chronological and hierarchical meaning of the ordinal numbers, on the other hand, from the point of view of the very composition and intelligibility of the myth, the ordinal numbers are precisely one of the things that structure and make perceivable the general progressive degeneration of the races. As a result, the presentation of the general degeneration of the races will not be satisfactorily grasped in its performance (insofar as performance refers to not only the poet but also the listener or reader: cf. U. Eco 1997, 33) until the chronology and hierarchy involved in the ordinal numbers are fully clarified.

Up until now, the topic of the ordinal numbers in Hesiod's myth of the races has not yet received the attention it deserves. Curiously, there is a general silence among Hesiod scholars about the question of what the meaning and function of the ordinal numbers in Hesiod's myth are. J. Fontenrose $(1974,7)$ renders $\delta \varepsilon v ́ \tau \varepsilon p o l$

\footnotetext{
${ }^{1}$ On the myth of the races having several organizing principles and not just one, see besides G. W. Most (1998) 109 - also T. M. Falkner (1995) 52.

${ }^{2}$ Cf. M. L. West (1978) 174: "It has long been recognized that the Heroes have been inserted (whether by Hesiod or a predecessor) into a system of four metallic races, each worse than the one before." G. W. Most (1998) 105-8 offers a fairly complete overview of the reception of Hesiod's myth (from Antiquity to modern scholarship) as one of degeneration. However, discussions about this topic are still going on - see L. Koenen (1993) 4; G. W. Most (1998) 119; J. S. Clay (2003) 81-2; R. Gagné (2010) 9. For the view that the succession of the races does not reflect degeneration, see F. Bamberger (1842) 534; W. Hartmann (1915) 19-20, 30, 58; F. J. Teggart (1947) 52; T. G. Rosenmeyer (1957) 269-77; J. Fontenrose (1974) 8; P. Smith (1980) 145, 158; T. M. Falkner (1995) 63-5; G. W. Most (1998) 109; R. Gagné (2010) 9 .
} 
in 142 as "of second rank;" but he does not say a word about the meaning of the other ordinal numbers. Both L. Koenen $(1993,7)$ and J. S. Clay $(2003,95)$ suggest an opposition between a chronological and a hierarchical understanding of the order of succession of the races; but neither of the two relates this opposition to divergent interpretations of the meaning and function of the ordinal numbers. Nevertheless, a sort of tacit agreement may be inferred from such a strange silence on the part of the commentators on Hesiod's poem: the ordinal numbers are implicitly taken to merely express the chronological order of the races. A view such as this implies that it is considered fairly obvious and not worthy of any discussion that the ordinal numbers are in themselves neutral in terms of the hierarchy of the races (although it is undeniable that in the myth some races are superior or inferior to others). To my knowledge, only a very small number of scholars (briefly and very insufficiently) approach the subject of the meaning and function of the ordinal numbers in the myth of the races. G. Wakker (1990, 88), G. W. Most (1998, 108-9), C. Calame (2004, 73, 76, 80), R. Nünlist $(2007,39)$ and R. Gagné (2010, 9) understand the ordinal numbers in the myth chronologically. B. Gatz $(1967,34)$ speaks of an "Abstufung;" but this is basically all we get from him as far as the idea of a hierarchical meaning and function of the ordinal numbers is concerned.

I will examine each and every one of the ordinal numbers that appear in Hesiod's myth, in order to determine whether or not they consistently possess both a chronological and a hierarchical meaning and function. Since the chronological meaning and function of the ordinal numbers in the myth seem to be either implicitly or explicitly recognized by other scholars, the main focus of this article will therefore be placed on verifying that the hierarchical dimension of the ordinal numbers is fairly consistently effective throughout the entire myth of the races. I will argue that even in the cases in which the article's main thesis appears to be less convincing, the ordinal numbers preserve at least a quantum minimum of their hierarchical dimension.

However, this is not the only way the present article intends to make a contribution to our understanding of the Hesiodic myth of the races. In addition to showing that the ordinal numbers used by Hesiod in the myth of the races involve both a chronological and a hierarchical sense, the article will also indicate how the ordinal numbers with a chronological and a hierarchical value are one of the linguistic resources that allow Hesiod to structure and effectively communicate to his audience a myth intended to present a general degeneration of the races. Indeed, the ordinal numbers are one of the elements through which Hesiod introduces the description of each of the races in their chronological and overall hierarchical succession. Moreover, especially when the poet uses ordinal adjec- 
tives, the ordinal numbers play a defining role in terms of identifying the races. Finally, if we compare the structuring of the myth by means of the ordinal numbers with other ways of structuring it, we find that the ordinal numbers are preserved throughout the myth, whereas, for example, the reference to the metals, which is one of the fundamental organizing principles of the myth, is interrupted when the race of heroes is described.

As regards Hesiod's use of, inter alia, the ordinal numbers to structure and communicate the degeneration of the races there is a general pattern in the poet's use of them in the myth. As we shall see, the pattern admits slight variations or deviations, which can be explained by the way Hesiod operates under the rules of Greek language in order to express the degeneration of the races while taking as his starting point material inherited from cultural tradition. Consequently, by means of the analysis of the use of the ordinal numbers in the Hesiodic myth of the races, the present article will focus on a particular example of how the composition of Hesiod's Works and Days is carried out on the basis of the interaction between the message the poet intends to communicate in each context, the preestablished rules of Greek language (as well as the expectations of the listener or reader insofar as they submit themselves to these rules in the process of understanding the poem) and the material inherited from cultural tradition both by the poet and the listener or reader. ${ }^{3}$

\section{II}

One of the possible functions of ordinal numbers in Greek is to express the rank of someone or something in a given hierarchy (cf. H. G. Liddell, R. Scott \& H. S.

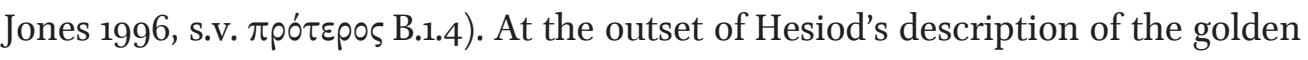
race, in the very first occurrence of the ordinal numbers in the myth of the races,

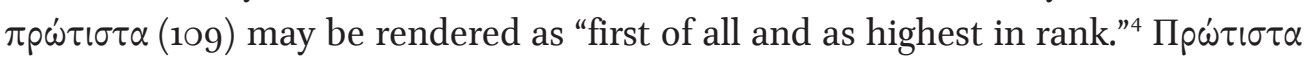

\footnotetext{
${ }^{3}$ Cf. W. A. Johnson (2006) 232-3: "what we seek to recover is that set of conventions, often unconscious, shared between audience and poet and informing the [...] response to the poetry."

${ }^{4}$ Pace C. Calame (2004) 73, who maintains that $\pi \rho \omega \dot{\tau} \tau \sigma \tau \alpha$ is merely "d'ordre chronologique." For other occurrences of $\pi \rho \omega \dot{\tau} \tau \sigma \tau \alpha$ in Hesiod, cf. J. Paulson (1962) s.v. In Th. 24, 116, the hierarchical sense of $\pi \rho \omega \dot{\tau} \tau \sigma \tau \alpha$ is clear - see W. H. Race (1992) 22, 23: "Forms of $\pi \rho \omega \hat{\omega}$ ov occur four times in the proem to indicate starting-points $(34,44,108$, 113), but the superlative $\pi \rho \omega \dot{\tau} \tau \sigma \tau \alpha$, which occurs only in lines 24 and 116 in the entire Theogony, designates the two beginnings of fundamental importance: 1) when Hesiod began his career as a poet, and 2) when the kosmos began from primal Chaos." Op. 405 and 458 are also cases of hierarchical $\pi \rho \dot{\omega} \tau i \sigma \tau \alpha$ : the former passage points to the most important of possessions for Perses to be able to clear his debts and ward off famine, while the latter one refers to the most decisive moment when the plowing season begins. The Hellenistic
} 
is an adverb and like the majority of adverbs it is formed from an adjective (see

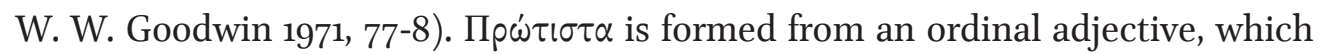
means that it is an ordinal adverb and may therefore include both a chronological and a hierarchical sense (cf. H. G. Liddell, R. Scott \& H. S. Jones 1996, s.v. $\pi \rho \dot{\omega} \tau i \sigma \tau \circ \varsigma)$. My claim is that the superlative form of the adverb conveys the idea that the golden race is the first in time and the highest in rank of a series of races that are depicted in the various sections of the myth. Although the golden race appears at the very beginning of the myth, it already points to a whole descending scale of races. ${ }^{5}$

Why does Hesiod start off in this way? Why does Hesiod use an ordinal adverb here, instead of using an ordinal adjective, which is what he does when describing each of the subsequent races (cf. 127, 143, 157, 174)? I believe Hesiod wants to point out right from the start that the whole descending scale of the races is a creation of the gods. Hesiod shows this by resorting to an adverb ( $\pi \rho \omega \dot{\omega} \tau \sigma \tau \alpha)$, which gives some prominence to the verb $\pi$ oin $\sigma \alpha \nu$ (110) and consequently to one of the many creation acts of the gods in the myth (cf. 128, 144, 158). Hesiod might

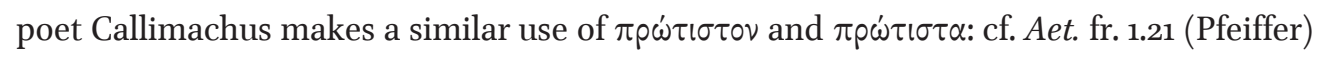
(a decisive moment in the poet's life), Del. 30 (the beginning of the narrative in contrast to previous uses of $\pi \rho \hat{\omega} \tau o v$ in $4,6,16,22)$. However, $\pi \rho \hat{\omega} \tau o v$ and its cognates are also used hierarchically. Both $\pi \rho \omega \hat{\tau} \tau o v$ and $\pi \rho \omega \dot{\tau} \tau \sigma \tau \alpha$ determine the climax in priamels: cf. Hes. Th. 116, h.Hom. 3.25, 214 - see W. H. Race (1982) 48, 53; W. A. Johnson (2006) 234. In Hom. Il. 1.6, 16.113, Od. 8.268, h.Hom. 3.25, 214, $\pi \rho \omega \hat{\tau} \tau \nu$ and $\tau \dot{\alpha} \pi \rho \hat{\omega} \tau \alpha$ mark the importance of an event rather than an absolute priority in time. In Call. Del. $\tau \dot{\alpha} \pi \rho \omega \hat{\tau} \tau$ (4) and $\pi \rho \dot{\omega} \tau \eta$ (6) designate qualitative and temporal priority. As W. H. Race (1992) 23-4 points out, $\pi \rho \hat{\omega} \tau o \mathrm{v}$ and primus are used throughout classical literature to indicate "primary events for narration," "truly significant starting-point[s]:" cf. Hom. Il. 1.6, Verg. Aen. 1.1, Prop. 1.1.1. The ancient Greeks considered their ancestors as better and closer to the gods than themselves

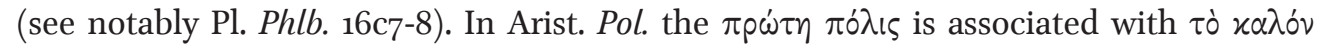
(1291a16-8); $\pi \rho \dot{\omega} \tau \eta$ and $\alpha \lambda \eta \theta i v \eta \dot{~(1294 a 25), ~ \pi \rho \omega ́ \omega \tau ~ a n d ~} \beta \varepsilon \lambda \tau i \sigma \tau \eta$ (1319a39) are coupled in hendiadys in the characterization of forms of government. Pericles funeral oration in $T h$.

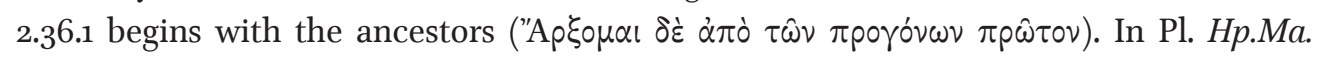
282a5-8 Hippias begins his speech by referring to the former generations for fear of the dead's resentment; it is implied in the passage that this is a usual procedure both for the speaker and his audience. On the ancient Greeks' positive evaluation of the past, see B. A. van Groningen (1953).

${ }^{5}$ Commenting on the use of $\pi p \omega$ tov in h.Hom. 3.19-25, 207-14, A. M. Miller (1986) 26 indicates that the term signals the starting point for a longer discourse. With respect to the fact that the use of ordinal numbers might create in the mind of a reader or listener the expectation that a counting will go on, cf. Hom. Il. 22.208; see M. M. Willcock (1984) 294; also N. J. Richardson (1993) 106, 125. 
have felt the need to stress the idea that human beings were created by the gods right after proposing to speak of "how the gods and mortal human beings came

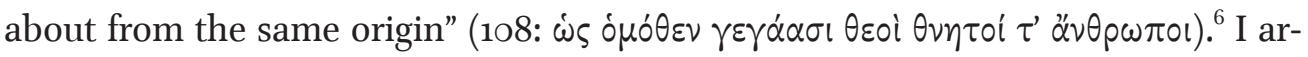
gue this since it is fairly clear that between the idea of human beings and the gods having a common origin and the fact that human beings were created by the gods, a conflict might arise, which as a result could cause confusion in the mind of a listener or reader. ${ }^{7}$ Moreover, by stressing the creation of the golden race by the gods, Hesiod might be intending to convey the idea that not even the highest of human races equals the gods in terms of rank in the cosmos as a whole. Hesiod is telling us that what follows is a chronological succession and at the same time a hierarchy (of which only the fourth race is partially excluded) of strictly human races. Right from their first appearance in the myth, the ordinal numbers seem to be conveying a clear message: that the golden race is of a supreme kind and is therefore placed at the very top of the chronology and hierarchy of men's imperfect races.

The superiority of the golden race in relation to the others is clearly pointed to by other indications throughout the myth. Multiple subsequent examples speak in favour of a hierarchical reading of $\pi \rho \omega \dot{\tau} \tau \sigma \tau \alpha$ (I will call attention to only a few of these other indications): the fact that Hesiod defines the first race as "of gold"

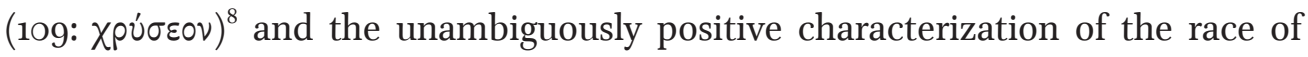
gold both before (112-20) and after (121-6) the death of its members. ${ }^{9}$ Hesiod's characterization of the golden race is widely known. Hence there is no need to go into detail in this respect. For the sake of economy, I have referred to the content and internal structure of Hesiod's description of the golden race in very general terms.

III

At the beginning of the description of the silver race, in the second appearance of

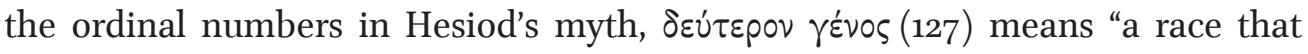

\footnotetext{
${ }^{6}$ For the use of the verb $\pi$ oเह่ $\omega$ to refer to the creation only of human beings, see C. Ramnoux (1959) 91; R. Sorel (1982) 26. Text, line numbers and translations of Hesiod with the exception of translations of ordinal numbers - are from G. W. Most (2010).

${ }^{7}$ On how this conflict might be solved, see S. A. Nelson (1998) 64: "As the gods, or Zeus, are said in this myth to 'make' each successive generation, Hesiod can only mean by 'springing from the same beginnings' that gods and human beings once lived alike."

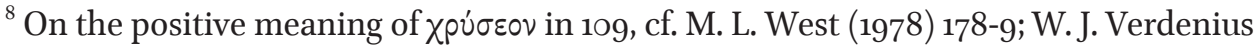
(1985) 79-80. For the symbolism of gold in general, see also J. Dillon (1992) 24; A. S. Brown (1998) 392-7.

${ }^{9}$ Commentators generally agree that the description of the golden race is entirely positive; but see J. S. Clay (2003) 87-8.
} 
comes second and is second in rank." ${ }^{m o}$ Hesiod is now resorting to an ordinal ad-

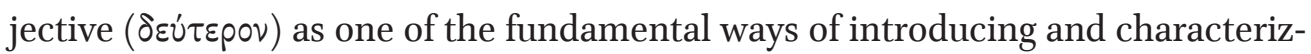
ing the silver race, which indicates that the connection between $\delta \varepsilon \dot{\tau \varepsilon p o v}$ and the noun ( $\gamma^{\varepsilon}$ vos) is such that the very identity of the $\gamma^{\varepsilon}$ vos at issue here is also determined by the fact that it is second both in time and rank; the same holds true mu-

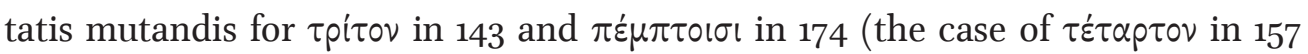
should be dealt with more carefully).

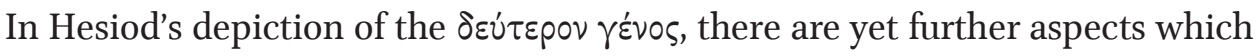
clearly indicate that this race is of an inferior nature in comparison with the previous one and therefore help to support a hierarchical interpretation of $\delta \varepsilon v i \tau \varepsilon \rho \nu$. The second race is also introduced and characterized as one "of silver" (128: apyúpєov); and silver is unarguably less valuable than gold (see R. Roth 186o, 11; V. Goldschmidt 1950, 34; F. Solmsen 1960, 182; E. R. Dodds 1973, 3; J. Fontenrose 1974, 2; J. Dillon 1992, 23; L. Koenen 1993, 4; G. W. Most 1998, 126; J.-P. Vernant 2007, 264). Hesiod explicitly refers to the silver race as "much worse" (127: $\pi 0 \lambda$ i

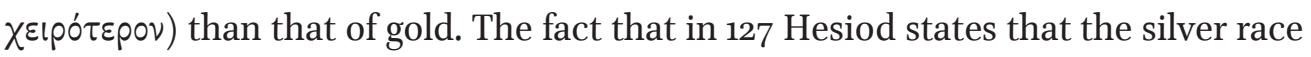
is $\pi 0 \lambda \dot{u} \chi \varepsilon 1 \rho o ́ \tau \varepsilon \rho \rho \nu$ does not make a hierarchical use of $\delta \varepsilon \dot{\tau} \tau \varepsilon \rho o v$ redundant. In fact, $\pi \circ \lambda \dot{\nu} \chi \varepsilon 1 \rho \circ \tau_{\varepsilon \rho \rho \nu}$ refers to the way the silver race is worse than the previous one. If

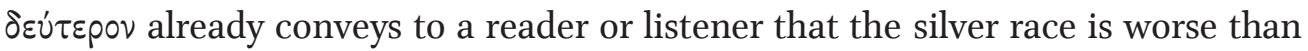
the golden one, $\pi \circ \lambda \dot{v} \chi \varepsilon$ вó $\varepsilon \varepsilon \rho \circ$, on the other hand, communicates the idea that the former is not merely worse but much worse than the latter. In 129 Hesiod states that the silver race is "like the golden one neither in body nor in mind"

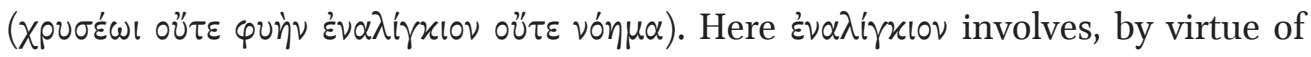
the connection between natural constitution and position in a hierarchy of races, the sense of "of similar rank" (see West 1978, 173, 184). The understanding of है $\alpha \lambda i \gamma$ iov as having to do with similarity of rank can find support in the meaning

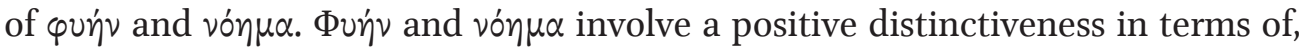
respectively, physical constitution and moral sentiment."

\footnotetext{
${ }^{10}$ On $\delta \varepsilon \dot{\tau} \tau \varepsilon p o \varsigma$ in the sense of "second (place or prize)," cf. Lexikon des frühgriechischen Epos s.v.; H. G. Liddell, R. Scott \& H. S. Jones (1996) s.v. A.1-3. $\Delta \varepsilon \dot{\tau} \tau \varepsilon p \circ \varsigma \pi \lambda \circ \hat{\varsigma}$ is a proverbi-

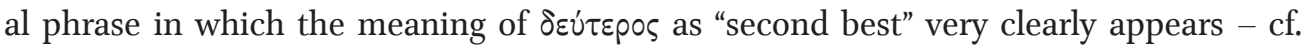
Corpus Paroemiographorum Graecorum 1.359-6o, 2.24-5 (Leutsch-Schneidewin). See also

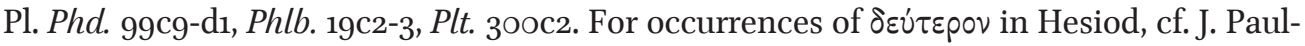

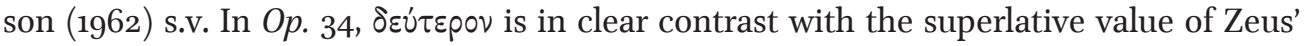

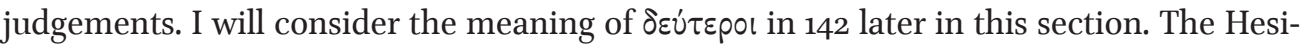

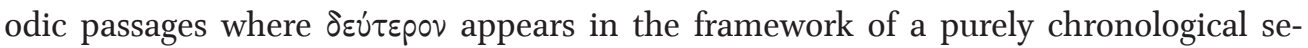
quence (Th. 47, 310 and 901) will be discussed in section VII.

${ }^{11}$ According to H. G. Liddell, R. Scott \& H. S. Jones (1996) s.v., $\varphi v \eta \dot{~-~ i n ~ H o m e r ~ a n d ~ H e s-~}$ iod - can be rendered as "noble stature;" cf. W. J. Verdenius (1985) 88. For vón $\mu \alpha$ Verdeni-
} 
Up to this point, Hesiod's presentation of the silver race is entirely negative. The silver race is manifestly worse than the race that precedes it and so far nothing in Hesiod's description even suggests that it can be better than any of the races that will exist thereafter. The second part of Hesiod's presentation of the silver race, however, will change this perception. 140-2 is the key passage in this respect. I will briefly indicate a couple of its important points. As Hesiod states in 141, after their death the members of the silver race "are called blessed mortals under the

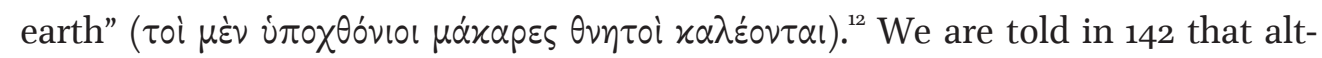
hough the members of the silver race "come second and are second in rank"

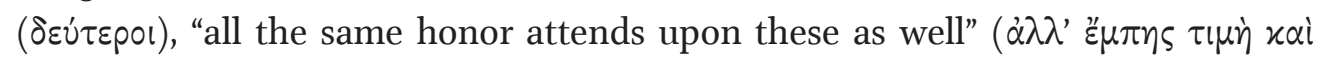

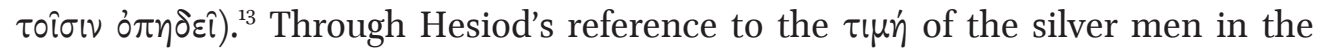
afterlife, it becomes clear that the silver race is superior to the race of bronze in this respect. ${ }^{14}$ In spite of a certain similarity between the race of silver and that of bronze - both races are characterized by üßpı (cf. 134-5, 145-6, 152; also J. S. Clay 2003, 82 and J.-P. Vernant 2007, 294-5) - the members of the latter "went down

us proposes "way of thinking." L. Koenen (1993) 3 gives the following paraphrase of 129: "lesser both in their physical appearance and in their morality."

${ }^{12}$ The claim that the second part of Hesiod's presentation of the silver race is a positive one is dependent upon the positive meaning of $\mu \alpha \dot{x} x \alpha \rho \varepsilon \varsigma$ here. M. L. West (1978) 186 clearly points to the positive meaning of $\mu \dot{\alpha} x \alpha p \varepsilon \varsigma$, even when the term is applied to the silver race: "They are $\mu \alpha \dot{x} x \alpha \rho \varepsilon \varsigma$ in the way that specially favoured mortals can be, after death, even without going to the $\mu \alpha \kappa \dot{\alpha} \rho \omega \nu$ vทेбol." See also U. v. Wilamowitz-Moellendorff (1962) 57. However, J. S. Clay (2003) 89-9o thinks otherwise; she takes the meaning of $\mu \dot{\alpha} x \alpha p \varepsilon \varsigma$ "to be euphemistic and apotropaic" and says that "The honor these evil spirits or ghosts receive resembles not the honor of cult [...] but the honor paid to the bad Eris [...], that is, in recognition of their power to harm, a power which is mitigated by calling them makares." Clay makes an interesting point here; but it does not affect the claim that in $141 \mu \alpha \dot{x} x \alpha \varepsilon \varsigma$ bears a positive meaning in terms of the silver race's rank in the hierarchy of the races. For although the power of the silver race's members is harmful - as Clay maintains - they are nevertheless powerful; in other words, they are of a high rank and therefore worthy of reverence.

${ }^{13}$ Cf. W. J. Verdenius (1985) 93: " $\tau \mu$ ' does not refer to the fact that they are worshipped by men, but to the fact that they have a special function, a privilege." The privilege (or special function) is due to them because of their high rank and intrinsic value. As Verdenius says, "we should not try to show that their afterlife is an appropriate answer to their life on earth" - a kind of reward for their (in fact inexistent) good deeds.

${ }^{14}$ Pace T. G. Rosenmeyer (1957) 270; J. Fontenrose (1974) 8; C. W. Querbach (1985) 3; J. S. Clay (2003) 82; J.-P. Vernant (2007) 261, 294. Cf. M. L. West (1978) 173: "Some scholars have doubted whether the Bronze men were conceived to be inferior to the Silver, but this is certainly implied by their fate after death: they dwell in Hades, nameless and unsung." 


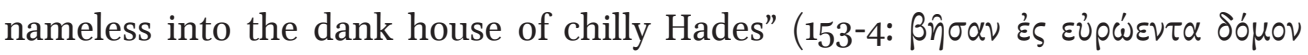

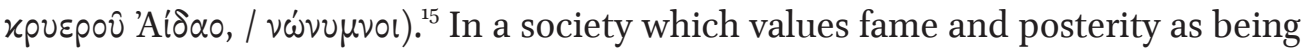
absolutely central, the lack thereof reflects an enormous decrease in value. ${ }^{16}$

One might argue that chronology suffices to explain the meaning of $\delta \varepsilon v i \tau \varepsilon p o v$ in 127 , for the silver race is also chronologically second. The fact that $\delta \varepsilon v i \tau \varepsilon \rho v$ involves a chronological sense is clear; however, explaining it simply by means of chronology amounts to understanding only part of the meaning implied in the term. In other words, it is not a matter of what suffices to explain $\delta \varepsilon v i \tau \varepsilon \rho v$, but rather a question of grasping the whole meaning that the term seems to involve in virtue of both its organizing function and its embedment in Hesiod's depiction of the silver race. If we leave aside the hierarchical dimension of $\delta \varepsilon v i \tau \varepsilon p o v$ because the term is explainable merely by way of chronology, we will be dealing only with one of the layers of meaning included in the ordinal adjective; the same is true of all the ordinal numbers in the myth.

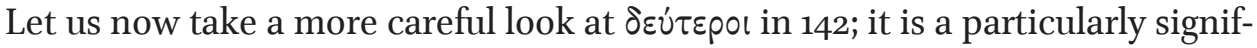
icant passage for several reasons. To begin with, it insists on the idea, which Hesiod has already and emphatically stated at the very beginning of 127 , that the men

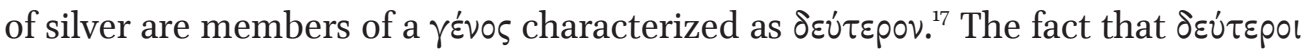
is in the plural means that Hesiod is explicitly referring to the members of the

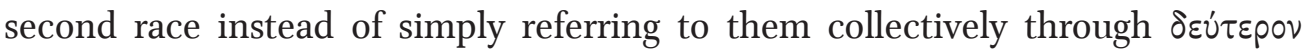
$\gamma \varepsilon$ '́vos. Secondly, in combination with the subsequent adversative phrase $-\alpha \lambda \lambda^{\prime}$

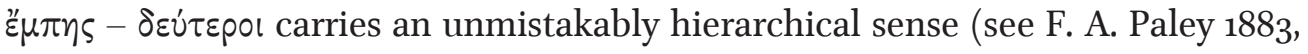
24; V. Goldschmidt 1950, 39; J. Fontenrose 1974, 7; M. L. West 1978, 187; W. J. Verdenius 1985, 93; A. Ballabriga 1998, 322). Insofar as it insists on the same idea that we find right at the beginning of 127 and as it also bears a clear hierarchical sense, $\delta \varepsilon v i \tau \varepsilon \rho$ s suggests that all the other ordinal numbers within the myth point to the relative hierarchical position of the races as well. Otherwise, we would have to admit that Hesiod is using the ordinal numbers inconsistently; it would be particularly strange to have two different uses of $\delta \varepsilon \dot{\tau \varepsilon p o v ~ i n ~ t h e ~ d e s c r i p t i o n ~ o f ~}$ the same race. Accordingly, though the meaning of $\delta \varepsilon v ं \tau \varepsilon \rho \circ$ in 142 is manifestly

${ }^{15}$ On the sense of $v \omega \dot{v} v \mu \nu$ ol, see W. J. Verdenius (1985) 98: "This does not mean that they [the members of the bronze race] do not get an honourable title like the two preceding races (which in fact is true), but that their name does not live on either in their fame $[\ldots]$ or in their posterity $[\ldots] . "$

${ }^{16}$ U. v. Wilamowitz-Moellendorff (1962) 59 makes a sharp contrast between the two races from the point of view of their renown or lack thereof: "Dieses Geschlecht [the bronze one] ist ab und tot; niemand weiß von ihm, während das silberne doch die Ehre

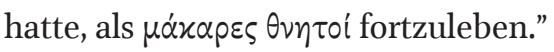

${ }^{17}$ See C. Calame (2004) 77: "deúteroi, au vers 142, en écho annulaire avec le vers 127." 
hierarchical, the chronological sense is nonetheless present; $\delta \varepsilon \dot{\tau \varepsilon p o l ~ i s ~ c o n n e c t e d ~}$ with $\delta \varepsilon u ́ \tau \varepsilon p o v$ in 127 and therefore with the fact that the silver men are also second in time. The fact that the verb is in the present tense does not mean that

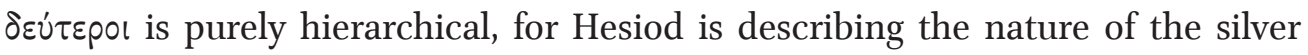
race in the framework of what is also a chronological sequence of the races. Hesiod uses the present tense because he is referring to the present function of the men of silver, but the function they perform in the present cannot be disconnected from their nature in the past. Thirdly, $\delta \varepsilon \dot{\tau \varepsilon p o l ~ i s ~ i n ~ a n ~ e m p h a t i c ~ p o s i t i o n: ~ i t ~ i s ~}$ placed at the very start of 142. The placing here should call our attention to its importance and consequently to the importance of the remaining ordinal numbers in situating each race in the chronological and hierarchical scale of the myth. Finally, it should be noted that the idea that the men of silver are only second best is picked up again in order to establish a clear relationship between the rank of the silver race on the one hand and its destiny in the afterlife on the other. Since the men of silver are only second best-and therefore inferior to the men of gold - they will consequently have a second best (or inferior) destiny in the afterlife (although nevertheless an honourable one).

IV

In their fourth occurrence, the ordinal numbers still involve both a chronological

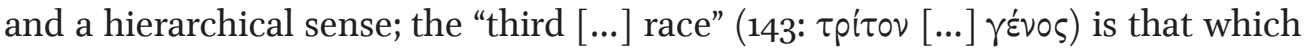
comes third and is third in rank..$^{18}$ Let us look at the way in which the content of the Hesiodic description of the bronze race is able to back up a hierarchical read-

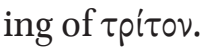

To begin, I will briefly point out a couple of characteristics of the bronze race which show that the bronze race is inferior to both the golden race and the silver race. The quality of the metal that defines the bronze race - the bronze race is characterized precisely as "of bronze" (144: $\chi \dot{\alpha} \lambda \varkappa \varepsilon\llcorner 0 \nu)$ - testifies to its inferiority in comparison with the two previous races. The fact that the race of bronze is of less value than the silver race - and a fortiori of less value than the golden race - is confirmed in 144, where Hesiod states that the race of bronze is "not similar to the

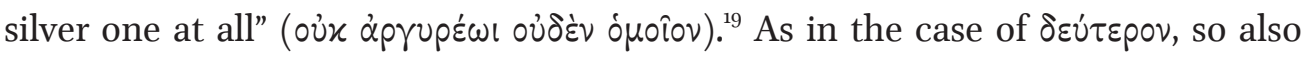

\footnotetext{
${ }^{18}$ On the hierarchical meaning of $\tau$ pi $\tau \circ \varsigma$, cf. H. G. Liddell, R. Scott \& H. S. Jones (1996) s.v. A.1. Apart from $O p$. 143, none of the references given by J. Paulson (1962) s.v. to the

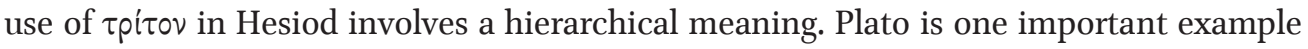
in Greek literature of the use of $\tau$ pi $\tau$ ov in the context of hierarchical orderings: see Phlb. 66c8-9, Lg. 728c9-d4, 739a1-e7; also sch. Pl. Grg. 451e.

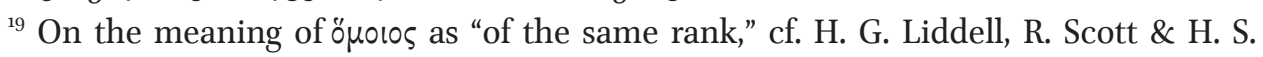
Jones (1996) s.v. A.2; M. L. West (1978) 187: "a cramped counterpart of 129.” W. J. Verdeni-
} 


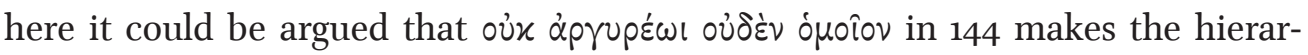

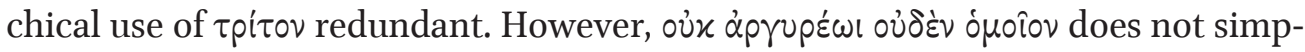
ly convey the idea of inferiority but a sort of intensified expression thereof. Ojx

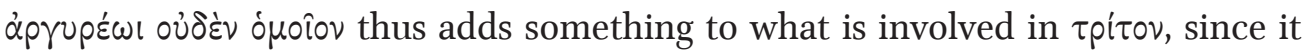
points to the fact that the bronze race is not simply worse but much worse.

However, Hesiod does not intend to draw an absolutely negative picture of the bronze race. In other words, Hesiod is not implying that the race of bronze does not possess any relatively positive characteristic and is therefore at the very bottom of the hierarchy of the races. According to Hesiod's description, the bronze race seems to be more valuable than at least the race of iron. 150-1 shows this very clearly; in this passage bronze appears in a positive light, in contrast to what Hes-

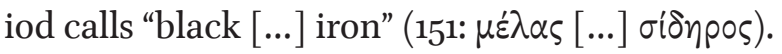

Let us examine more closely what kind of superiority bronze has in relation to iron. Is it a monetary or a symbolic kind of superiority? In terms of the relative monetary value of the metals gold is the most precious and silver the second most precious of the four metals referred to in Hesiod's myth of the races (see G. W. Most 1998, 126). However, there is no sufficient evidence for even starting a debate on the relative monetary value of bronze and iron in the Geometric and Archaic periods (see M. Y. Treister 1996, 96). Therefore, up to the race of bronze the idea of a hierarchy of the races can be backed up by what is historically known about the relative monetary value of the metals that qualify each race; but from the bronze race on, the way in which the metals might reflect a hierarchy of the races has to be explained otherwise. In fact, in the myth of the races the relative value of the metals does not necessarily have to be measured in terms of price. Apparently, Hesiod thought of bronze as more valuable than iron simply in

us (1985) 94 makes a pertinent observation: "Called by We. 'a cramped counterpart of 129', but Maz. (I), 62, rightly observes that Hes. emphasizes the fact that there is a gradual

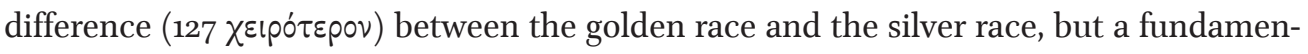

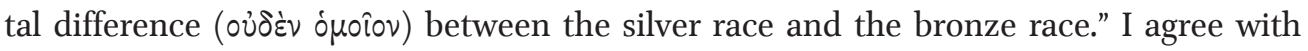
Verdenius that 144 is not merely a "cramped counterpart of 129," but I do not think - and in this I disagree with Verdenius and Mazon - that the use of oủ óv vis intended to convey that the difference (of rank) between the silver race and the bronze race is more fundamental (or more radical) than the difference between the golden race and the silver race. In using oủ ¿́s v instead of a comparative construction Hesiod seems to be simply referring to a difference of a similar kind - but in more emphatic (or more vehement) terms. On ópoílos (182) used as a synonym of ö $\mu 010$, see M. L. West (1978) 199; W. J.

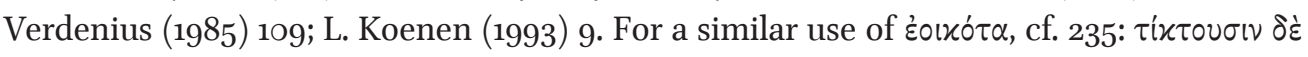

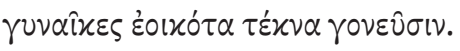


symbolic terms..$^{20}$ Indeed, bronze could easily be associated with earlier times, when human beings were supposedly bigger and stronger than today. ${ }^{21}$ Bronze must have been the most used metal in the days before the Homeric heroes were even born, for the ancestors of the Homeric heroes are unlikely to have become acquainted with iron. ${ }^{22}$

The present interpretation of the relative value of the bronze race in the context of Hesiod's myth of the races is able to support a hierarchical reading of

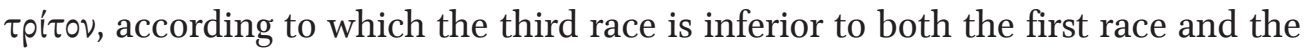
second race and superior to at least the fifth race.

However, before examining the fifth occurrence of the ordinal numbers in Hesiod's myth, let us briefly consider an important objection. Hesiodic scholarship has recently proposed the superiority of the bronze race in comparison with the silver one (see J. S. Clay 2003, 84-5, 91; also P. Smith 1980, 145, 158 and T. M. Falkner 1995, 63-5). According to this view, the members of the bronze race (who are older and physically stronger than those of the silver one) are superior to the members of the silver race. The objection is extremely interesting; but the question to be asked in the present context is whether age and physical strength are the most fundamental principles according to which the myth of the races was composed and its structure as a whole should be perceived. From my point of view, they are not the most fundamental principles according to which the whole Hesiodic myth of the races was structured. In a myth intended to explain the origin of evil and the necessity of work and justice in human society (see S. A. Nelson 1998, 48), the principle of progressive degeneration - conceived of as a general structuring principle - should prevail over the principles of age and physical strength. Due to their complexity, the composition and structure of Hesiod's myth can be understood from several points of view (such as those of age and physical strength); but these are secondary structuring principles in comparison with the primary structuring principle of general progressive degeneration.

\section{$\mathrm{V}$}

In the fifth occurrence of the ordinal numbers, $\tau \dot{\tau} \tau \alpha \rho \tau o v$ (157) seems to be used simply in a chronological sense. The fourth race is of a higher rank than at least

${ }^{20}$ Cf. B. Gatz (1967) 44-5; F. Lämmli (1968) 20; W. J. Verdenius (1985) 97; T. M. Falkner (1995) 67; G. W. Most (1998) 113: "Hesiod was [...] committed [...] to a highly negative symbolic interpretation of iron."

${ }^{21}$ Cf. sch. Hes. Op. 174 (Pertusi), where the scholiast refers to the members of the bronze race as the Giants; see also G. W. Most (1998) 121-2.

${ }^{22}$ On the historical significance of bronze, cf. J. G. Griffiths (1956) 112-4; B. Gatz (1967) 44-5; L. Koenen (1993) 25; G. W. Most (1998) 122-3, 124. For the use of metals in the Homeric world, see also R. J. Forbes (1967) 15-35. 
the previous and the subsequent race. ${ }^{23}$ In other terms, the meaning of this particular ordinal number seems to have been impoverished through elimination of its hierarchical dimension, since the content of the description of the fourth race in terms of its relative value is apparently not able to back up a hierarchical reading of $\tau \dot{\varepsilon} \tau \alpha \rho \tau o v .{ }^{24}$

The race of heroes, both in life and the afterlife, testifies to the fact that this race is superior to at least the bronze and the iron races. Hesiod tells us that the

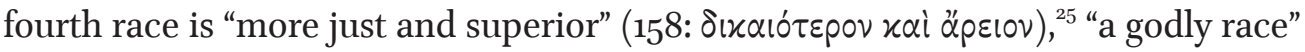

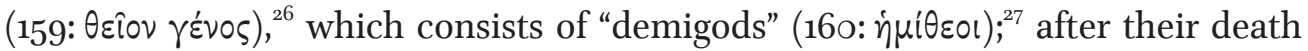

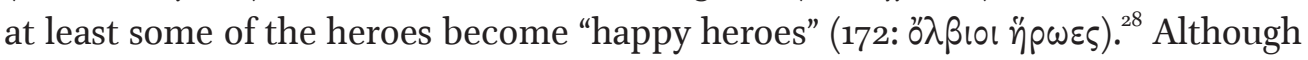

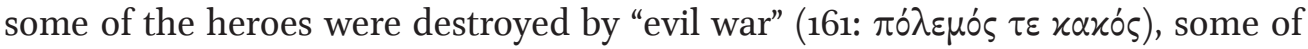

${ }^{23}$ On the inferiority of the race of heroes in relation to all the previous races in the myth, see M.-C. Leclerc (1993) 218-9; S. A. Nelson (1998) 70-4. A. Ballabriga (1998) 324 speaks of the "face noire de l'héroïsme." On the "dark side of heroism," see also A. Brelich (1958) 225-83.

${ }^{24}$ With the sole exception of Op. 157, all indications in J. Paulson (1962) s.v. as to the use of $\tau \dot{\varepsilon} \tau \alpha \rho \tau \sigma \varsigma$ or $\tau \dot{\varepsilon} \tau p \alpha \tau o \zeta$ in Hesiod point to a purely chronological meaning of the terms. For the use of $\tau \dot{\varepsilon} \tau \alpha \rho \tau \tau \varsigma \zeta$ in the framework of a hierarchical classification, cf. Pl. Phlb 66c8-9, sch. Pl. Grg. 451e and Plu. Alc. 11.

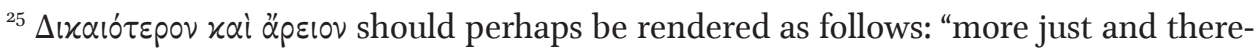
fore superior" - for the meaning of $x \alpha i$ here, cf. W. J. Verdenius (1985) 99; on the connec-

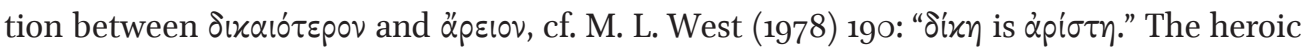

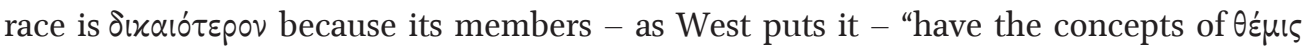
and $\delta$ íx;;" see also G. Nagy (1979) 155 .

${ }^{26}$ Cf. M. L. West (1978) 191: the heroes "were descended from gods, and themselves $\theta \varepsilon \circ \varepsilon i x \varepsilon \lambda \circ 1, \theta \varepsilon \circ \varepsilon 1 \delta \varepsilon \varepsilon \varsigma$, $\theta \varepsilon i ̂ l ; "$ also Verdenius (1985) 99: "the heroes, although mortal, are

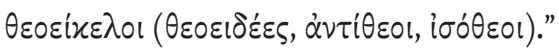

${ }^{27}$ See M. L. West (1978) 191: "the word refers to their parentage." W. J. Verdenius (1985) 99-10o does not agree with this: "in Homer [...] and Hes. the heroes are not said to be of semi-divine descent, and in the epic tradition this certainly was not the rule. The original meaning of the word seems to be 'almost gods' [...] apart from the immortality of the gods there was no sharp dividing-line between the gods and men, but only a gradual difference [...] Just as the gods in their actions and feelings may sink to the human level, prominent men may conversely rise to the level of the gods [...]." Despite appearances,

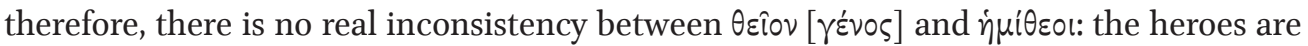
members of a "divine [race]" because they are "almost gods" in the way they behave.

${ }^{28}$ See W. J. Verdenius (1985) 104: "[The word means] 'Happy on account of god-given abundance."” 
them fought for apparently good causes. ${ }^{29}$ An example of this would be those that fought at Thebes and Troy (cf. 167-73). Though nothing is said about the reason why some of the heroes went to the islands of the blest and others did not, it is likely that moral behaviour was the decisive factor. ${ }^{30}$ The fact that the heroes fought in war, and that at least some of them died in war, can be seen as a sign of their moral inferiority (especially because this is a characteristic of the bronze men as well; cf. 145-6 and 161-5). Moreover, it should be borne in mind that not all heroes went to the isles of the blest - which is a negative aspect that must be taken into account when assessing the place of the heroic race in the hierarchy of the races. Nevertheless, all in all, Hesiod draws a generally positive picture of the heroic race - a picture in which the heroic race is superior to the bronze and the iron races. By introducing the heroic race into the myth, Hesiod therefore conveys the idea of a broken degeneration of the races.

Up to the introduction of the race of heroes, the use of the ordinal numbers, both in a chronological and a hierarchical sense, is one of the organizing principles in the presentation (on the part of the poet) and understanding (on the part of a reader or listener) of the succession of the races. So much emphasis is given to it that Hesiod continues to resort to the ordinal numbers even when a race superior to the previous one is at stake and consequently the content of the description of this race does not apparently admit an interpretation of the respective ordinal number as being hierarchical too. We may speak of an impoverishment in 157 in the sense that $\tau \dot{\tau} \tau \alpha \rho \tau o v$ seems to lack a hierarchical dimension and therefore half of the total richness of meaning possessed by the other ordinal numbers in the myth. The impoverishment occurs here because Hesiod happens to decide to introduce a race that is higher in value than the preceding one, and in this way wishes to follow the Homeric tradition of praising the heroes of a somewhat distant past and to be faithful (from at least the fourth race on) to a certain (partly legendary) chronology of Greek history. ${ }^{31}$

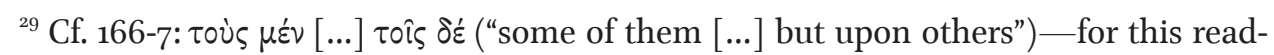

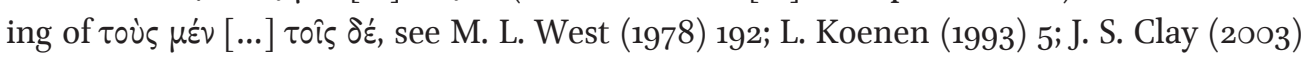
93. M. L. West (1978) 192 does not agree with Solmsen that 166 is an interpolation.

${ }^{30}$ See N. J. Richardson (1974) 314, 316. However, W. J. Verdenius (1985) 102 says that Hesiod "does not specify their names [the names of the heroes], for that would have involved him in the difficulty that some morally outstanding heroes, such as Patroclus and Hector, did not escape death."

${ }^{31}$ On how the order in which the metals are presented in the myth of the races mirrors the chronology of Greek history according to archaeological data, see J. G. Griffiths (1956) 112, 113. G. W. Most (1998) 121-2 argues that the bronze race might have been inspired by the ancestors of the Homeric heroes and therefore suggests that even the 
However, the fact that there is an impoverishment does not invalidate the main thesis of this article. First, the impoverishment does not affect all the ordinal numbers in the myth but, at least so far, only one. Second, the hierarchical dimension of the ordinal numbers is only momentarily lost or put on standby. In fact it becomes effective again a short time afterwards at the very moment when the next race is introduced, for the fifth men are inferior to the members of all the four previous races. The position of the fourth race in relation to the fifth indi-

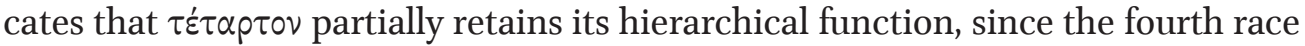
is superior to the fifth. It can therefore be claimed that only a partial or limited impoverishment is at stake in 157 .

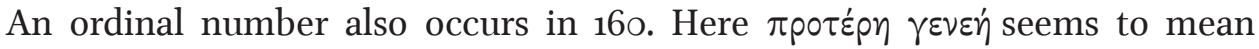
simply "the generation before our own" (cf. F. A. Paley 1883, 27; T. A. Sinclair 1932, 21; U. v. Wilamowitz-Moellendorff 1962, 59; M. L. West 1978, 191; W. J. Verdenius 1985, 100; G. W. Most 1998, 101). However, it might not be totally lacking in a hierarchical sense. Indeed, it might mean that the heroes not only precede us but are also superior to us (that is, to the iron race); in this case, it would express the superiority of the heroes in relation to the iron men. If this is correct - and maintaining that the heroic race is superior to at least the bronze one and that Hesiod's myth is therefore presenting a momentarily interrupted degeneration of the races - then the degeneration from the heroic to the iron race forms a smaller descending scale within a larger overall descending scale from the golden to the iron race.

Among Hesiod scholars there is some discussion about the meaning of $\gamma \varepsilon v \varepsilon \eta$ in

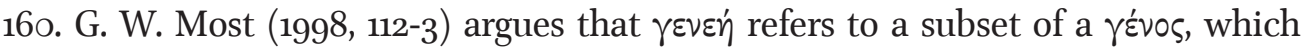
implies that both the heroes and the members of the race of iron belong to one and the same $\gamma^{\varepsilon}$ v $v$ s. ${ }^{32}$ However, apart from the fact that the heroes and the iron men are

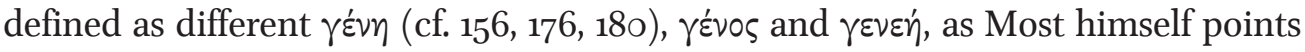
out, are sometimes synonyms. R. Gagné $(2010,10)$ maintains that "The fact that

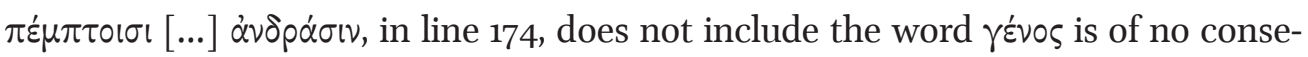
quence" for the question of the distinction between ${ }^{\varepsilon} v 0 \varsigma$ and $\gamma \varepsilon v \varepsilon \eta \dot{~}$. According to his view, such a fact cannot be presented as evidence that $\gamma \varepsilon \dot{v} 0 \varsigma$ and $\gamma \varepsilon v \varepsilon \eta \dot{~ b e a r ~ d i f-~}$ ferent senses in Hesiod's myth, nor therefore as evidence that the heroes and the

bronze race might belong to a (legendary) understanding of the chronological order in Greek history. For the relationship between Hesiod's metals and Greek history, see also F. Bamberger (1842) 525; V. Goldschmidt (1950) 34; R. Nünlist (2007) 50.

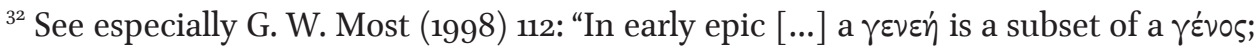
the term distinguishes from one another members of two subgroups who all belong to the same $\gamma^{\varepsilon}$ vंo s but who differ from one another by being born earlier or later and hence belong to different generations." 
iron men belong to different subgroups of one and the same $\gamma^{\varepsilon}$ vos. Furthermore, S. A. Nelson $(1998,75)$ argues that "Hesiod makes no attempt to establish any continuity between the ages." The significance behind this theory is that $\gamma \varepsilon v \varepsilon \eta \dot{~ m a y ~ n o t ~}$ necessarily imply that the heroes and the men of iron are more closely related than any other pair of $\gamma \varepsilon \dot{v} \eta$. I believe that, for the above-mentioned reasons, when Hesi-

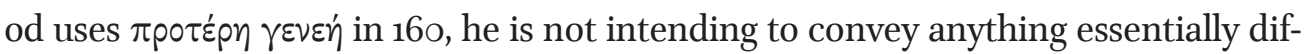

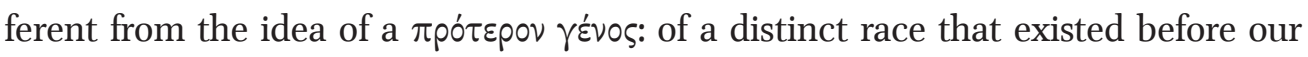
own (iron) race and was therefore also superior to it.

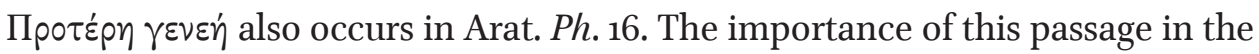
present context is twofold. First, it is borrowed from Hesiod's Works and Days, and second, it bears a clearly hierarchical sense. Much discussion has taken place among Aratus scholars about the meaning of Arat. Ph. 16 (see D. Kidd 1997, 172-3; H. van Noorden 2015, 169). D. Kidd $(1997,173)$ indicates that Aratus is referring to "the race of gods as opposed to the human race." According to Kidd, "A[ratus] here may be seen to have updated Hesiod by eliminating the $\dot{\eta} \mu^{\prime} \theta \varepsilon 0$ of of $O p$. 160 and promoting Hesiod's phrase to the divine level." K. Volk $(2012,225)$ argues that Aratus is pointing to the golden race. Kidd seems to be right on this matter; but in

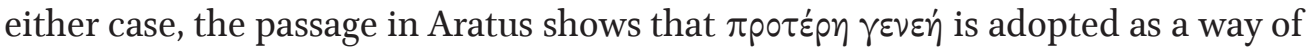
referring to a race that is superior to the one that lives in the present. Not only is it natural to conceive of the race of the immortals or that of the golden men as the most superior races, but it is also the case that in the Aratus passage $\pi \rho \circ \tau \dot{p} \eta$

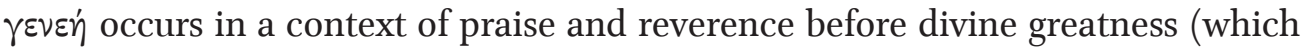
may concern either the immortal gods or the divine race of the golden men). As it is borrowed from Hesiod and seems to possess a hierarchical dimension, the passage in Aratus shows that it is likely that the passage in $O p$. 160 involves a hierarchical sense.

VI

In $174 \pi \varepsilon \dot{\varepsilon} \mu \pi \tau \circ \sigma$ l is used as an ordinal number in its full sense, as is the case at least in the first four occurrences of the ordinal numbers (109, 127, 142, 143). $\Pi \varepsilon \dot{\mu} \mu \tau \tau \iota \sigma \iota$ refers both to the fact that the iron race is the fifth race in order of appearance and to the fact that it is fifth in rank. ${ }^{33}$

In 174-5 Hesiod does not use the phrase "fifth race." Hesiod speaks rather of "the fifth men." However, this does not mean that he conceives of these men otherwise than as members of a race (cf. 176 and 180, where Hesiod uses the term "race" in the context of the description of the time in which the fifth men live); if

\footnotetext{
${ }^{33}$ No indication of hierarchical $\pi \dot{\varepsilon} \mu \pi \tau \circ \varsigma$ in J. Paulson (1962) s.v. apart from Op. 174. H. G. Liddell, R. Scott \& H. S. Jones (1996) s.v. $\pi \dot{\varepsilon} \mu \pi \tau 0 \varsigma$ do not refer to it either, but the term occurs in Pl. Phlb 66c8-9 with a hierarchical meaning.
} 
the fifth men are members of a race, the race to which they belong can be called the fifth race.

Why then does Hesiod deviate from the general pattern ( $\gamma$ Évos in conjunction with an ordinal adjective) that he usually applies when introducing a new race

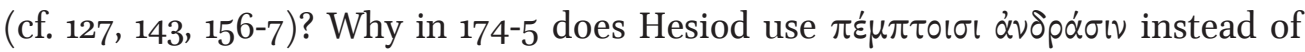

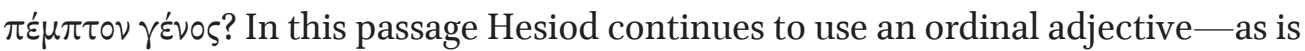
the case in the introduction of the three previous races-but changes the noun accompanying it. What is the meaning of $\dot{\alpha} \nu \delta \rho \dot{\alpha} \sigma \nu$ here? Why is the term used in (violent) enjambment? ${ }^{34}$ If the term is placed in such an emphatic position, it is likely to be carrying a new, important meaning for our understanding of the myth and in particular of the character of the iron race. Hesiod's choice of the term, and consequently the above-mentioned change of pattern, would then be quite justified.

In order to answer these questions, I will first try to determine what the mean-

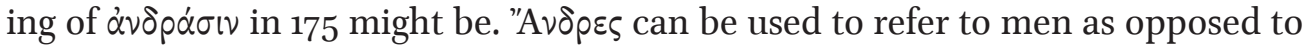
either the gods or monsters (see M. Hofinger 1978, s.v. ঝे $\nu$ p 1; H. G. Liddell, R.

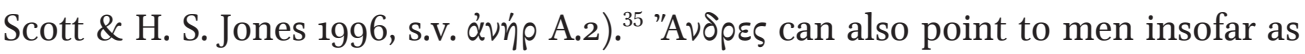
they live in societies and cities (see T. W. Allen, W. R. Halliday \& E. E. Sikes 1936,

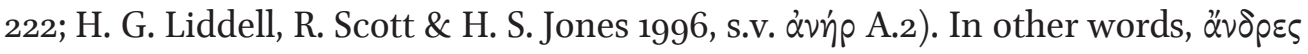
can express both the hierarchical position of human beings in the cosmos (that is, the idea that human beings occupy an intermediate place between the gods and other living creatures in the hierarchy of the cosmos as a whole) and the fact that human beings live together in organized communities.

Among the possible meanings of $\alpha^{\prime} \nu \delta \rho \varepsilon \varsigma$, the idea of a hierarchical position and that of life in society are crucial for us to understand what Hesiod is trying to convey when he changes from $\gamma^{\varepsilon} v o \varsigma$ to $\alpha \dot{\nu} \delta \dot{\alpha} \sigma \omega v$. Hesiod is saying that the fifth men are distinct and separated from the gods (and indeed far more distinct and separated from the gods than any one of the previous four races; cf. 112, 141-2, 145$6,158-60,170-3)$. Hesiod is also saying that the fifth men are present-day men living with each other in communities very much like the ones we ourselves live in (with all the vices and all the hardship that come with it). In other words, in 175 Hesiod prefers not to use a noun ( $\gamma \varepsilon$ vं०५) that is neutral as to whether or not the

${ }^{34}$ On violent enjambment, cf. G. S. Kirk (1976) 146-82, especially 148-50. On enjambment and its function in Homer and Hesiod, see also G. S. Kirk (1965) 24; G. P. Edwards (1971) 93-9, 191; M. Parry (1971) 251-65; G. S. Kirk (1985) 30-7; M. van Raalte (1986) 65-7, 388 .

${ }^{35}$ Pace C. Calame (2004) 80, who states that $\alpha$ $\alpha \delta \rho \varepsilon \varsigma$ refers specifically to "hommes qui partagent [...] avec les dieux une part de leur divinité originaire." The use of $\alpha v \delta \rho \alpha ́ \sigma \nu$ in 175 strongly speaks against Calame's understanding of ä $\nu \delta \rho \varepsilon \varsigma$ in the myth of the races. 
fifth men have anything to do with us, both in terms of nature and way of life, and decides instead to use another noun ( $\left.\alpha \dot{\nu} \delta \alpha_{\alpha} \sigma / v\right)$ that can evoke the injustice and the suffering of our race. Hesiod uses $\alpha \dot{\alpha} \nu \rho \rho \varsigma \varsigma$ once in the context of the description of the heroic race (164). The meaning behind this is that the heroes and the iron men share a relatively similar nature, although in the final analysis they belong to different races (see W. J. Verdenius 1985, 105; S. A. Nelson 1998, 75; R. Gagné 2010, 10; pace G. W. Most 1998, 112-3). In other words, the heroes seem to be exposed to the same kind of injustice and suffering as the iron men, but, unlike the latter, the former are able to excel in terms of the quality of their deeds and end up being rewarded with a better destiny in the afterlife than that which awaits the iron men during their lifetime (cf. 174-201). However, the fact that in 175 the $\alpha \dot{\alpha} \delta \rho \varepsilon \varsigma$ are labelled as fifth makes it clear that Hesiod does not mean the heroes but the iron

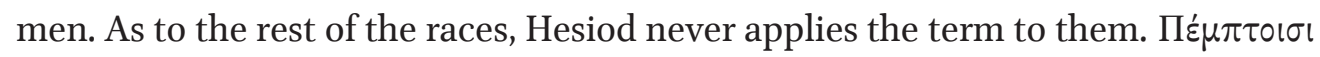
$\alpha \nu \delta \rho \alpha \dot{\sigma} v$ therefore clearly indicates that Hesiod is now going to talk about our own race and especially about its wretched character.

Nevertheless, a question remains: why does Hesiod not use $\alpha \dot{\alpha} \theta \rho \omega \pi 0$ instead of $\alpha 2 v \delta \rho \varepsilon \varsigma$ ? The answer might be that $\alpha \nu \theta \rho \omega \pi$ or is a more general and abstract term, which occurs in the description of all the races (cf. 108, 109, 123, 137, 143, 167, 180, $195,199,201)$ and cannot therefore distinctively refer to the race of iron as our own race. ${ }^{36}$ Be that as it may, insofar as the $\alpha^{\prime} \nu \delta \rho \varepsilon \varsigma$ are members of a race (namely the iron race, which is our race: see sch. Hes. Op. 174 Pertusi; F. A. Paley 1883, 28; W. J. Verdenius 1985, 105), the change in the aforementioned pattern does not in the least affect the claim that the ordinal numbers generally function as a hierarchical positioning of Hesiod's races.

Let us now see whether or not the description of the iron race speaks in favour of the presence of a hierarchical dimension in $\pi \dot{\varepsilon} \mu \pi \tau 0 เ \sigma$. The description should confirm whether or not $\pi \dot{\varepsilon} \mu \pi \tau 0 \iota \sigma$ points to the fact that the iron race is fifth in rank and therefore worse than all the previous four races. According to Hesiod's description, the iron race is indeed the worst of the races. Of all the metals in the

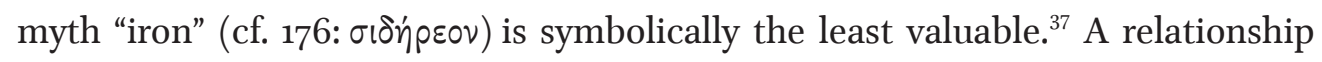
exists, for instance, between the physical appearance of iron and iron as a metal

${ }^{36}$ On $\alpha 2 \vartheta \rho \omega \pi \circ \varsigma$ as a broader term, see M. Hofinger (1978) s.v. 1; H. G. Liddell, R. Scott \&

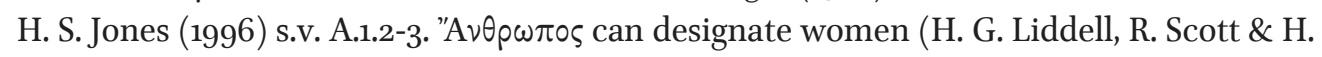

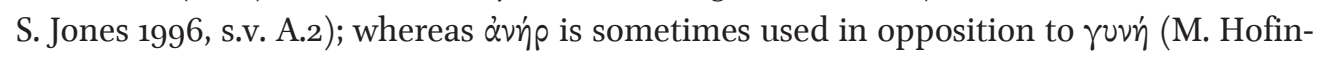
ger 1978, s.v. 2). When $\alpha \nu \theta \rho \omega \pi \circ \varsigma$ is applied to individuals it usually expresses irony, pity or contempt (H. G. Liddell, R. Scott \& H. S. Jones 1996, s.v. A.1.4-6). It can also serve as a way of addressing slaves (H. G. Liddell, R. Scott \& H. S. Jones 1996, s.v. A.1.7).

${ }^{37}$ For a summary account of the relative value of the metals in the myth of the races, see V. Goldschmidt (1950) 34; M.-C. Leclerc (1993) 221-3; A. S. Brown (1998) 395. 
symbolizing a gloomy state of affairs (cf. 150-1). ${ }^{38}$ However, the most powerful testimony to the inferiority of the iron race is to be found in 174-5, when Hesiod expresses his escapist wish: "If only then I did not have to live among the fifth men,

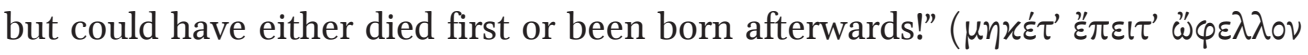

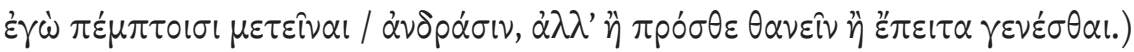

In favour of the superiority of the iron race in comparison with the other races depicted in the myth (especially the race of silver and that of bronze), it could be argued that in the iron race "good things will be mingled with evil ones" (179:

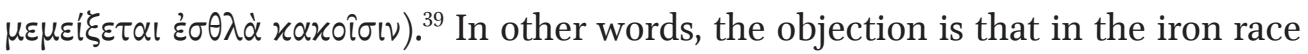
there are good things (even though they are "mingled with evil ones"), whereas in the silver and bronze races, there seem to be no good things at all. However, I believe 179 does not refer to a state of affairs in the present but to one desired for the future..$^{40}$ In my perspective, $\mu \varepsilon \mu \varepsilon i \xi \varepsilon \tau \alpha$ (on the one hand) and the futures in the rest of the section on the iron race (on the other hand) do not point to the same state of affairs. The futures in the section on the iron race (with the exception of the future in 179) are, as T. G. Rosenmeyer $(1957,276-7)$ puts it, instances of a "deterministic future," in the sense that what results from the way in which the members of the iron race behave is "bound to occur, and will continue to occur for some time, as long as men remain iron." ${ }^{41}$ As to $\mu \varepsilon \mu \varepsilon i \xi \varepsilon \tau \alpha l$ in 179 it refers to a possible state of affairs in the future, in which the iron men start to behave more justly. According to this view the present state of affairs, which Hesiod calls the iron race, is an evil one. The fact that it can become better is not a legitimate argument against the claim that Hesiod's characterization of the present state of affairs in the iron race is a most negative one.

${ }^{38}$ See G. W. Most (1998) 125 on $\pi 0 \lambda$ ıós associated with iron. For the relationship between $\pi 0 \lambda_{1}$ 's and old age, cf. T. M. Falkner (1995) 67, 278.

${ }^{39}$ See M.-C. Leclerc (1993) 222: "Le bronze est le métal connoté le plus négativement chez Hésiode. Même le fer se trouve en quelques emplois neutres, de même que les hommes de la dernière race voient présentement quelques biens mêlés à leurs maux."

${ }^{40} \mathrm{Cf}$. Verdenius (1985) 108: "The optimistic note of 179 seems to be based on Hes.'s self-confidence as a moral preacher: the preceding story has shown a degeneration in the development of mankind, but also the possibility of escaping divine punishment. The permanent order of the world established by Zeus ties up the present to the past, but leaves open a margin of human choice which may modify the future. Accordingly, Hes. is convinced that his argument might save his contemporaries from further degeneration, and he proleptically includes this perspective in his gloomy picture [...]."

${ }^{41}$ Although W. J. Verdenius (1985) 106-7 criticizes Rosenmeyer, I do not find that Rosenmeyer's interpretation of the sense of the future tense in the section on the iron race is incompatible with Verdenius' idea that Hesiod "regards his own lifetime as the beginning of a period in which matters will become worse and worse." 
However, even if Hesiod's entire description of the iron race might be taken to refer to a present state of affairs, there can hardly be any doubt as to the negative character of the iron race as a whole. For although the mingling of good and bad things might refer to a present state of affairs, Hesiod's description of the iron race makes it clear that, overall, bad things prevail over good ones. Indeed, in the entire description of the iron race, 179 is actually the only time a partially positive characteristic can be found (in the sense that good things are referred to precisely as apparently always mingled with bad ones). According to the assessments of the silver and the bronze races, their positive characteristics are not only purely positive ones but also refer to clearly defined topics and matters of greater religious and mythological importance - they have to do with issues such as being favoured by the gods (cf. 141), destiny in the afterlife (cf. 142), the symbolism of the metals (cf. 144 and 150-1), bodily strength and physical constitution, whereas in the description of the iron race what the good things exactly amount to remains undetermined.

In conclusion, it may be said that the content of the description of the iron race speaks in favour of the hierarchical reading of $\pi \dot{\varepsilon} \mu \pi \tau 0 เ \sigma$. Hesiod's description of the iron race does indeed show that it is the worst of all the races in the myth and that it is placed at the very bottom of the whole hierarchy of the races. The meaning of $\pi \dot{\varepsilon} \mu \pi \tau 0 เ \sigma \mathrm{l}$ in terms of hierarchy is precisely that of "fifth" in the sense of "worse than the preceding four" or "the worst of five."

\section{VII}

Overall the ordinal numbers found in the myth of the races bear both a chronological and a hierarchical sense. On two occasions (109-10, 174-5) Hesiod slightly deviates from a general pattern that consists in the use of an ordinal adjective together with Yévos (cf. 127, 143, 156-7) when he introduces each race. The slight deviations from the pattern can be explained by (among other things) the context of each of the passages and the specific message Hesiod is conveying to his public on each of these occasions. However, both are indeed only slight deviations, which are in fact totally in agreement with the idea of a generally descending scale of races structurally framed by a series of ordinal numbers (mainly an ordinal adjective in conjunction with a noun specifically referring to certain types of human nature and world, and in only one instance an ordinal adverb in conjunction with a verb of creation).

The ordinal numbers do not just come in isolation but in conjunction with terms that seem to point to a more purely chronological understanding: $\mu \dot{\varepsilon} v$

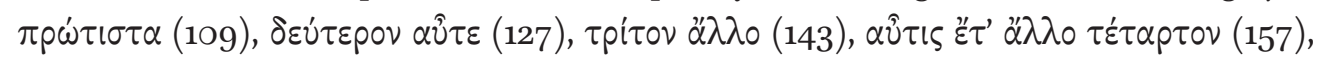

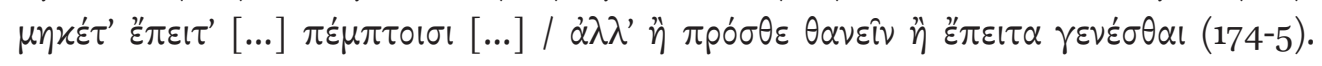


However, the fact that such terms involve a chronological sense does not mean that the hierarchical one is not present, for the latter is closely linked to the former in the sense that what comes first or before is superior.

A few passages in the Hesiodic corpus present a series of interrelated ordinal numbers that are purely chronological: $T h .43^{-52}, 309-15,886-921$. These passages are significantly different from the overall hierarchical scale of the myth of the races. All of them occur in contexts where an account of the relative value of what is being chronologically listed is absent: $43-52$ indicates the chronological order in which the Muses glorified the gods with their song; 309-15 chronologically enumerates Typhon's children with Echidna; 886-921 lists in chronological order Zeus' wives or sexual partners up to his marriage with Hera. The linguistic similarities and parallelisms between these passages and the ordering of the myth of the races are merely partial and do not point to an identity of meaning. The chronological sequence of $T h .43-5^{2}$ is marked by two ordinal numbers in the

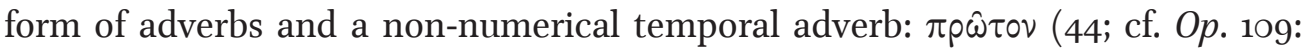

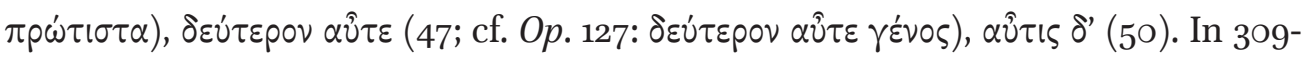
15 the chronological sense of the enumeration is made plain by a sequence of

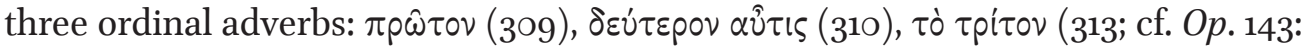

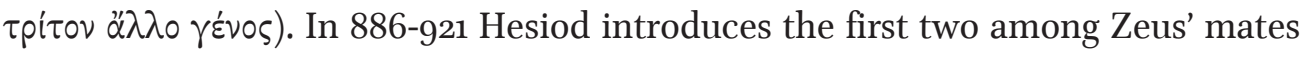
by means of ordinal numbers: an ordinal adjective (886: $\left.\pi \rho \omega \dot{\tau} \tau \nu \alpha^{2} \lambda \circ \times \circ \nu\right)$ and an

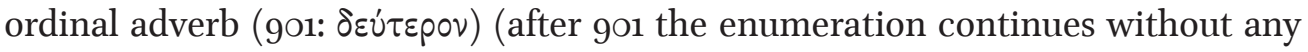
use of ordinal numbers). A comparison between the chronological markers in the Theogony passages and the ordinal numbers in the myth of the races demonstrates that for the most part they are fundamentally different in terms of linguistic construction and function. None of the passages in the Theogony shows a consistent chronological ordering by means of ordinal numbers. When ordinal numbers are used in these passages, they mainly occur in the form of ordinal adverbs (with the single exception of 886 , the meaning of which is strictly chronological). The connection between ordinal adjectives and nouns designating entities with relative hierarchical value, which is one main element indicating the hierarchical dimension of the ordinal numbers in the myth of the races, is lacking

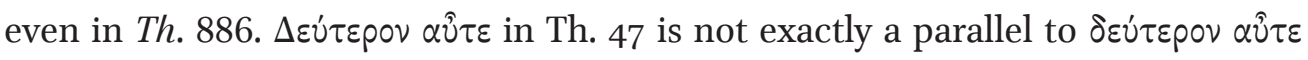

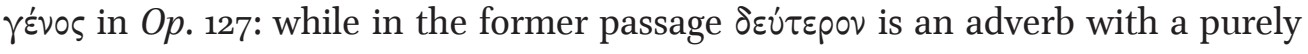
chronological sense, in the latter one $\delta \varepsilon \dot{\tau \varepsilon \rho o v}$ is an adjective defining the identity of a Yévos that Hesiod describes as being second in rank. In the only case in the myth of the races where an ordinal adverb occurs (109), $\pi \rho \omega \dot{\tau} \tau \tau \tau \alpha$ bears a hierarchical sense in contrast to the purely chronological meaning of $\pi \rho \omega \hat{\tau}$ ov in Th. 44 and 309. By virtue of these differences, the purely chronological sense of the or- 
dinal numbers in the Theogony passages does not invalidate that those occurring in the myth of the races involve a hierarchical dimension.

In Pl. Grg. 451e3-5 Socrates quotes three lines of a well-known anonymous scholion. As E. R. Dodds indicates in his commentary (1959, 200), "The fourth item is omitted by Plato, since it does not depend on any $\tau \dot{\varepsilon} \chi \nu \eta$," which is the main subject of discussion between Socrates and Gorgias at this point in the dialogue. The full four-verse scholion can be found in sch. Pl. Grg. 451e2 (Green). It consists of a hierarchical ordering of a set of values, the origin of which is aristocratic, but which seem to be widespread and shared by the ancient Greek community in general, at least in the classical period (see E. R. Dodds 1959, 200). The hierarchical ordering in the scholion is structured mainly by means of ordinal numbers, with the sole exception of the very first line: "Health is best for a mortal man; second to be born fair in nature; third to be rich without deceit; and fourth

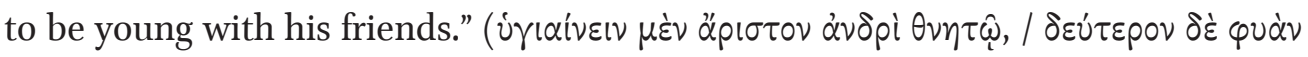

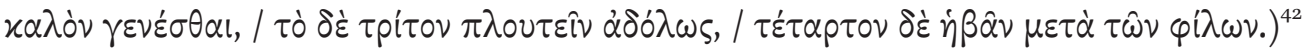
The scholion is worth mentioning because the fact that this kind of compositions is usually sung at symposia, and is either traditional or extemporized, indicates that the ancient Greeks are familiar with poetic displays of, and disputes on, scales of values. ${ }^{43}$ The ordinal adverbs in the scholion are deeply embedded in its evaluative content and bear an unmistakably hierarchical sense (especially by

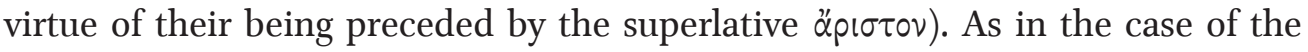
myth of the races, the evaluative context in which the ordering occurs, is one decisive aspect determining the hierarchical meaning of the ordinal adverbs. Such a context is totally absent from the Theogony passages considered above, which is one of the reasons why the ordinal numbers in these passages are purely chronological. ${ }^{44}$ The fact that the scale in the scholion begins with ápı $\sigma \tau o v$ and not with an ordinal number such as $\pi \rho \dot{\omega} \tau i \sigma \tau \alpha$ is not relevant in terms of the similarity between the hierarchical ordering of the scholion and that of the myth of the races.

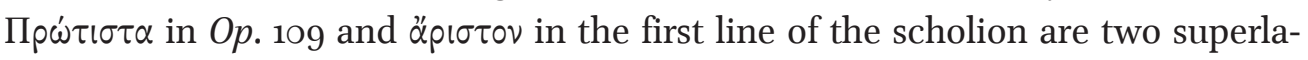
tives with a marked and similar evaluative sense. In light of the affinities between

\footnotetext{
${ }^{42}$ The translation is by T. Irwin (1979) 115 .

${ }^{43}$ The well-attested form of the priamel shows various ways in which these contentions are displayed in ancient Greek literature: cf. Hom. Il. 2.76o-7o, Tyrt. fr. 12 (West), Sapph. fr. 16.1-4 (Lobel-Page), Pi. O. 1.1-7, Pl. Ly. 211d7-e8, Grg. 448c3-9, Smp. 211b7-d1, 221c2-d6, Phdr. 240a9-c1; Lg. 661a4-c5 represents an interesting case in which a numerical hierarchical scale of values partially merges with the form of the priamel. On the priamel in classical literature, see notably W. H. Race (1982).

${ }^{44}$ This is also the case with two numerical priamels in Callimachus: Ap. 72-6 and Dian. $119-22$.
} 
the hierarchical scales in the myth of the races and in such a usual kind of poetic composition as the scholion, it seems natural for Hesiod to create, and for his audience to be able to perceive, an overall hierarchical scale such as that of the myth of the races by consciously or unconsciously resorting to the ordinal numbers. One of the powers of the ancient Greek language, which it shares with other languages, is precisely to build and make perceivable hierarchical scales of cultural material by means of linguistic resources such as ordinal numbers.

\section{REFERENCES}

Allen, T. W., Halliday, W. R. \& Sikes, E. E. ed. (1936, 2nd edn) The Homeric Hymns. Oxford.

Ballabriga, A. (1998) "L'invention du mythe des races en Grèce archaïque," RHR 215, 30739 .

Bamberger, F. (1842) “Über des Hesiodus Mythus von den ältesten Menschengeschlechtern," RhM 1, 524-34.

Brelich, A. (1958) Gli eroi greci: un problema storico-religioso. Roma.

Brown, A. S. (1998) "From the Golden Age to the Isles of the Blest," Mnemosyne 51, 389410.

Calame, C. (2004) "Succession des âges et pragmatique poétique de la justice: le récit hésiodique des cinq espèces humaines," Kernos 17, 67-102.

Clay, J. S. (2003) Hesiod's Cosmos. Cambridge.

Dillon, J. (1992) "Plato and the Golden Age," Hermathena 153, 21-36.

Dodds, E. R. ed. (1959) Plato: Gorgias. Oxford.

Dodds, E. R. (1973) "The Ancient Concept of Progress," in: E. R. Dodds, The Ancient Concept of Progress and Other Essays on Greek Literature and Belief. Oxford, 1-25.

Eco, U. (1997, 4th edn) Opera aperta: forma e indeterminazione nelle poetiche contemporanee. Milano.

Edwards, G. P. (1971) The Language of Hesiod in Its Traditional Context. Oxford.

Falkner, T. M. (1995) The Poetics of Old Age in Greek Epic, Lyric, and Tragedy. Norman, Oklahoma.

Fontenrose, J. (1974) “Work, Justice, and Hesiod's Five Ages,” CPh 69, 1-16.

Forbes, R. J. (1967) Bergbau, Steinbruchtätigkeit und Hüttenwesen. Göttingen.

Gagné, R. (2010) “Invisible Kin: Works and Days 280-285," Hermes 138, 1-21.

Gatz, B. (1967) Weltalter, goldene Zeit und sinnverwandte Vorstellungen. Hildesheim.

Goldschmidt, V. (1950) "Théologia," REG 63, 20-42.

Goodwin, W. W. (1963, 2nd edn) A Greek Grammar. London.

Greene, W. C. ed. (1938) Scholia Platonica. Haverford.

Griffiths, J. G. (1956) “Archaeology and Hesiod's Five Ages," JHI 17, 109-19.

Hartmann, W. (1915) De quinque aetatibus Hesiodeis. Freiburg.

Hofinger, M. (1978) Lexicon Hesiodeum cum indice inverso. Leiden.

Irwin, T. trans. (1979) Plato: Gorgias. Oxford. 
Johnson, W. A. (2006) "Hesiod's Theogony: Reading the Proem as a Priamel," GRBS 46, 231-5.

Kidd, D. ed. (1997) Aratus: Phaenomena. Cambridge.

Kirk, G. S. (1965) Homer and the Epic: A Shortened Version of "The Songs of Homer." Cambridge.

Kirk, G. S. (1976) Homer and the Oral Tradition. Cambridge.

Kirk, G. S. (1985) The Iliad: A Commentary. Vol. 1. Cambridge.

Koenen, L. (1993) "Greece, the Near East, and Egypt: Cyclic Destruction in Hesiod and the Catalogue of Women," TAPhA 124, 1-34.

Lämmli, F. (1968) Homo faber: Triumph, Schuld, Verhängnis? Basel.

Leclerc, M.-C. (1993) "Le mythe des races: une fiction aux sentiers qui bifurquent," Kernos 6, 207-24.

Leutsch, E. L. v. \& Schneidewin, F. W. ed. (1839) Corpus Paroemiographorum Graecorum. Vol. I. Göttingen.

Liddell, H. G., Scott, R. \& Jones, H. S. (1996, 9th edn) A Greek-English Lexicon, with a revised Supplement. Oxford.

Lobel, E. \& Page, D. ed. (1955) Poetarum Lesbiorum fragmenta. Oxford.

Miller, A. M. (1986) From Delos to Delphi: A Literary Study of the Homeric Hymn to Apollo. Leiden.

Most, G. W. (1998) "Hesiod's Myth of the Five (or Three or Four) Races," PCPhS 43, 10427.

Most, G. W. ed. (2010, rev. edn) Hesiod: Theogony, Works and Days. Cambridge, Massachusetts.

Nagy, G. (1979) The Best of the Achaeans: Concepts of the Hero in Archaic Greek Poetry. Baltimore.

Nelson, S. A. (1998) God and the Land: The Metaphysics of Farming in Hesiod and Vergil. Oxford.

Nünlist, R. (2007) "Hesiod," in: I. J. F. de Jong \& R. Nünlist, ed. Time in Ancient Greek Literature: Studies in Ancient Greek Narrative. Vol. 2. Leiden, 39-52.

Paley, F. A. ed. (1883) The Epics of Hesiod. London.

Parry, M. (1971) "The Distinctive Character of Enjambment in Homeric Verse," in: A. Parry, ed. The Making of Homeric Verse: The Collected Papers of Milman Parry. Oxford, $251-65$.

Paulson, J. ed. (1962, 2nd edn) Index Hesiodeus. Hildesheim.

Pertusi, A. ed. (1955) Scholia vetera in Hesiodi Opera et Dies. Milano.

Pfeiffer, R. ed. (1949) Callimachus. Vol. I. Oxford.

Querbach, C. W. (1985) "Hesiod's Myth of the Four Races," CJ 81, 1-12.

Race, W. H. (1982) The Classical Priamel from Homer to Boethius. Leiden.

Race, W. H. (1992) "How Greek Poems Begin," YCS 29, 13-38.

Ramnoux, C. (1959) La Nuit et les enfants de la nuit dans la tradition grecque. Paris.

Richardson, N. J. ed. (1974) The Homeric Hymn to Demeter. Oxford.

Richardson, N. J. (1993) The Iliad: A Commentary. Vol. 6. Cambridge. 
Rosenmeyer, T. G. (1957) “Hesiod and Historiography," Hermes 85, 257-85.

Roth, R. (1860) Der Mythus von den fünf Menschengeschlechtern und die indische Lehre von den vier Weltaltern. Tübingen.

Sinclair, T. A. ed. (1932) Hesiod: Works and Days. London.

Smith, P. (1980) "History and the Individual in Hesiod's Myth of Five Races," CW 74, 14563.

Snell, B. ed. (1991) Lexikon des frühgriechischen Epos. Vol. 2. Göttingen.

Solmsen, F. (1960) "Hesiodic Motives in Plato," in: Hésiode et son influence. VandoeuvresGenève, 171-211.

Sorel, R. (1982) "Finalité et origine des hommes chez Hésiode," RMM 87, 24-30.

Teggart, F. J. (1947) "The Argument of Hesiod's Works and Days," JHI 8, 45-77.

Treister, M. Y. (1996) The Role of Metals in Ancient Greek History. Leiden.

Van Groningen, B. A. (1953) In the Grip of the Past: Essay on an Aspect of Greek Thought. Leiden.

Van Noorden, H. (2015) Playing Hesiod: The "Myth of the Races" in Classical Antiquity. Cambridge.

Van Raalte, M. (1986) Rhythm and Metre: Towards a Systematic Description of Greek Stichic Verse. Assen.

Verdenius, W. J. (1985) A Commentary on Hesiod (Works and Days, vv. 1-382). Leiden.

Vernant, J.-P. (2007) Oeuvres. Vol. 1. Paris.

Volk, K. (2012) "Letters in the Sky: Reading the Signs in Aratus' Phaenomena," AJPh 133, 209-40.

Wakker, G. (1990) "Die Ankündigung des Weltaltermythos (Hes. Op. 106-108)," Glotta 68, 86-9o.

West, M. L. ed. (1978) Hesiod: Works \& Days. Oxford.

West, M. L. ed. (1992) Iambi et Elegi Graeci. Oxford.

Wilamowitz-Moellendorff, U. v. ed. (1962, 2nd edn) Hesiodos Erga. Berlin.

Willcock, M. M. ed. (1984) The Iliad of Homer: Books XIII-XXIV. London. 